\title{
CHEMICAL COMPOSITION OF THE ALKALOID EXTRACT ISOLATED FROM HYLOTELEPHIUM SPECTABILE (BOREAU) H. OHBAX TELEPHIUM (L.) H. OHBA AERIAL PARTS*
}

Miloš G. Đukić ${ }^{* *}$, Jelena M. Jovanović, Gordana S. Stojanović, Snežana Č. Jovanović

Department of Chemistry, Faculty of Science and Mathematics, University of Niš, Niš, Serbia

There are many motives to study alkaloids within Crassulaceae family, such as chemotaxonomic consideration of alkaloid distribution and evaluation of their biological potential. Data on alkaloids from Sedum telephium (syn. H. telephium) aroused interest for further alkaloid investigation within the genus Hylotelephium $\mathrm{H}$. Ohba. Thus, the aim of this study was to investigate and characterize other plant sources of alkaloids from the same genus. An alkaloid extract (AE-HS) was isolated from fresh aerial parts of a cultivated hybrid $H$. spectabile $\times$ telephium. The chemical composition of AE-HS was determined by GC-MS (gas chromatography - mass spectrometry) method. Eight components were identified, which made up $91.8 \%$ of the sample. The most present component of AE-HS was $\mathrm{Y}$-crotonolactone $(78.6 \%)$ followed by 3-methyl-2-butenal $(8.6 \%)$ and $(E)$-coniferyl alcohol (2.8\%). Nicotine was identified as the only alkaloid in the AE-HS $(0.4 \%)$. Along with many non-alkaloid compounds, a previous study found six alkaloids in $\mathrm{AE}$ of $\mathrm{S}$. telephium ( 7\%), suggesting differences from our results. Additionally, alkaloid distribution is limited within other genera of the family and belonging to the same genus does not mean a uniform qualitative composition. Further analyzes of AEs of Hylotelephium taxa would certainly shed light on the pattern of alkaloid distribution.

\section{Introduction}

Hylotelephium $\mathrm{H}$. Ohba is considered to belong to the genera of the Crassualaceae family. It had been classified as a section or subgenus of Sedum, until 't Hart (1995) redefined it as a separate genus. It contains about 33 species, spread in the temperate parts of East Asia, Europe, and North America. Some Hylotelephium species are consumed fresh (leaves) or cooked (leaves, roots). In traditional medicine various species of the genus $\mathrm{Hy}$ lotelephium are used for skin diseases treatment, such as burns, pimples, wounds, as well as in anti-inflammatory and analgesic treatments [1-3]. The distribution of alkaloids is generally limited within the genus Sedum L. (Sedum acre-group); Several types of alkaloids have been identified - pyrrolidines and piperidines (2-monosubstituted and 2,6-disubstituted), which were considered in previous chemotaxonomic studies [4,5]. Phytochemical studies on the genus comprise several classes of secondary metabolites distributed in different plant organs: flavonoids, glucosides tannins, alkaloids, terpenes, lactones, organic acids, and polysaccharides [2,6-11]. According to published data, extracts of the studied Hylotelephium species showed several biological activities: high antioxidant and anti-inflammatory activity of $H$. erythrostictum aerial parts extract; antimicrobial and antioxidant activity of
(ORIGINAL SCIENTIFIC PAPER) UDC 582.711.16:547.94

DOI 10.5937/savteh2102005D

Keywords: Hylotelephium spectabile $\mathrm{x}$ telephium, alkaloids, GC-MS analysis

\footnotetext{
*The paper was presented at $14^{\text {th }}$ Symposium with international participation "NOVEL TECHNOLOGIES AND ECONOMIC DEVELOPMENT", Faculty of Technology in Leskovac, 22-23 October, 2021.

**Author address: Miloš G. Đukić, Faculty of Science and Mathematics, University of Niš,

Višegradska 33, 18000 Niš, Republic of Serbia,

e-mail: milos.djukic@pmf.edu.rs

The manuscript received: July, 07, 2021.

Paper accepted: September, 01, 2021.
}

leaf and flower extracts, fractions and hydrolysates of $H$. spectabile $\mathrm{x}$ telephium; anti-inflammatory and analgesic activity of the $H$. kamtschaticum methanol extract $[1,12]$. In addition to the listed biological activities, $H$. spectabile is characterized by the strong accumulation power of $\mathrm{Cd}$ without growth inhibition [1].

$H$. spectabile (Boreau) H. Obha x telephium (L.) H. Ohba, a plant hybrid; parentage: $H$. spectabile (Boreau) $\mathrm{H}$. Ohba and H. telephium (L.) H. Ohba. It is widespread in Serbian horticulture, grown as an ornamental plant and used in traditional medicine [2,9]. Previous studies on $H$. spectabile $\mathrm{x}$ telephium reported flavonoid profile of leaves and flowers characterized by different contents of flavonoid glucosides and flavonoid aglycones in methanol extracts, their hydrolysates and fractions [9] and profiles of volatile compounds isolated from root by headspace technique and hydrodistillation [2]. Although the distribution of alkaloids is generally limited to the acre-group members, the study by Gerelt-Od et al. (2015) found data on alkaloids from Sedum telephium (syn. H. telephium), which aroused interest in alkaloid investigation in the aerial parts of other Hylotelephium species [6]. The aim of this study was to investigate other plant sources of alkaloids from the same genus. Thus, the alkaloid extract was isolated 
from the aerial parts of $H$. spectabile $x$ telephium (AE-HS) and characterized by GC-MS. The results obtained are discussed with respect to literature data.

\section{Experimental}

\section{Plant material}

The fresh aerial parts (stem with leaves) of cultivated plant $H$. spectabile $x$ telephium were collected in October (2020) from garden pots. A voucher (No 6853) specimen was deposited at the Herbarium fund of the Faculty of Science and Mathematics, University of Niš (HMN).

\section{Extraction of the plant material}

Prior to extraction, the collected aerial parts of the plant $H$. spectabile $\mathrm{x}$ telephium were cleaned and cut into small pieces. The weighed plant material $(300 \mathrm{~g})$ was placed in a dark laboratory flask, filled with $600 \mathrm{~mL}$ of methanol, and extracted by maceration for seven days. After extraction, the plant material was removed by filtration, and methanol was evaporated under reduced pressure. The alkaloid extract (AE-HS) was isolated from the residue according to the described procedure [6]. The obtained alkaloid extract (52 mg, yield $0.02 \%$, w/w) was dissolved in dichloromethane $\left(20 \mathrm{mg} \mathrm{mL}^{-1}\right)$ for further GC-MS analysis.

\section{GC-MS analysis}

The GC-MS analysis was performed on a 7890/7000B GC/MS/MS triple quadrupole mass spectrometer (Agilent Technologies, USA) with Combi PAL auto sampler. The separation of components was done on HP-5MS column ( $5 \%$ phenylmethylsiloxane, $30 \mathrm{~m} \times 0.25 \mathrm{~mm}$, film thickness of stationary phase $0.25 \mu \mathrm{m})$. Carrier gas was helium (99.999\%) with flow $1 \mathrm{~mL} \mathrm{~min}^{-1}$. Different temperature programs were used and the best separation of compounds was under the following conditions: a temperature program of $50{ }^{\circ} \mathrm{C}$ for $1 \mathrm{~min}$, then $2{ }^{\circ} \mathrm{C} \min ^{-1}$ to $300{ }^{\circ} \mathrm{C}$; injection volume $2 \mu \mathrm{l}$, and split ratio 1:40. The contribution of the compounds was determined as the share of surface of every peak in the total surface of total ion chromatogram (TIC). Data processing was performed using AMDIS software (Automated Mass Spectral Deconvolution and Identification System, version 2.7) and NIST MS Search program (National Institute of Standards and Technology, version 2.0). The identification of the compounds was performed by comparing the retention indices of the compounds with the retention indices of $\mathrm{C}_{8}-\mathrm{C}_{40}$ n-alkanes recorded on the same column and under the same GC-MS operating conditions, and their mass spectra with those listed in the mass spectrum libraries.

\section{Results and discussion}

The results on chemical composition of the alkaloid extract of the species $H$. spectabile $x$ telephium are summarized in Table 1.
Tabela 1. Chemical composition of the alkaloid extract isolated from the $H$. spectabile $x$ telephium aerial parts

\begin{tabular}{|c|c|c|c|c|c|c|}
\hline No. & RI & LI & MS data & MF & Compound & $\begin{array}{c}\text { Composition } \\
(\%)\end{array}$ \\
\hline 1. & 784 & 778 & $\begin{array}{c}84(99.9), 55(59.6), \\
56(9.2), 85(4.6), \\
53(2.5), 54(2.3), 82(1.6) \\
83(0.7), 86(0.5), 57(0.4)\end{array}$ & $\mathrm{C}_{5} \mathrm{H}_{8} \mathrm{O}$ & 3-Methyl-2-butenal & 8.6 \\
\hline 2. & 837 & $839^{\circ}$ & $\begin{array}{l}\text { 59(99.9), 101(63.0), } \\
58(37.0), 98(13.3), \\
83(9.3), 56(7.5) \\
55(5.0), 57(4.0) \\
60(3.5), 102(3.0)\end{array}$ & $\mathrm{C}_{6} \mathrm{H}_{12} \mathrm{O}$ & $\begin{array}{l}\text { 4-Hydroxy-4- } \\
\text { methyl-2-pentanone }\end{array}$ & 0.3 \\
\hline 3. & 927 & $924^{*}$ & $\begin{array}{l}55(99.9), 84(78.9), \\
54(19.2), 53(4.6), 85 \\
(3.7), 56(3.5), 83(2.6) \\
82(0.9), 52(0.5), 57 \\
(0.3)\end{array}$ & $\mathrm{C}_{4} \mathrm{H}_{4} \mathrm{O}_{2}$ & Y-Crotonolactone & 78.6 \\
\hline 4. & 1112 & 1107 & $\begin{array}{l}91(99.9), 92(57.2), \\
\text { 122(31.0), 65(11.8), } \\
\text { 77(4.9), 93(4.3), } \\
78(3.8), 51(3.6), \\
89(3.5), 63(3.2)\end{array}$ & $\mathrm{C}_{8} \mathrm{H}_{10} \mathrm{O}$ & Phenethyl alcohol & 0.4 \\
\hline 5. & 1343 & 1342 & $\begin{array}{l}\text { 84(99.9), 133(30.3), } \\
\text { 162(20.5), } 161(18.9), \\
\text { 119(8.1), 85(6.3), } \\
\text { 92(5.8), 118(5.4), } \\
82(4.8), 130(4.5)\end{array}$ & $\mathrm{C}_{10} \mathrm{H}_{14} \mathrm{~N}_{2}$ & Nicotine & 0.4 \\
\hline 6. & 1455 & $1459^{*}$ & $\begin{array}{l}\text { 121(99.9), 152(38.2), } \\
93(18.4), 65(11.1), \\
\text { 122(6.7), 153(3.3), } \\
63(2.7), 151(2.3), \\
64(2.2), 92(2.1)\end{array}$ & $\mathrm{C}_{8} \mathrm{H}_{8} \mathrm{O}_{3}$ & Methylparaben & 0.4 \\
\hline 7. & 1522 & 1513 & $\begin{array}{l}\text { 119(99.9), 91(96.3), } \\
\text { 79(69.2), 107(54.9), } \\
\text { 105(41.5), 77(36.8), }\end{array}$ & $\mathrm{C}_{10} \mathrm{H}_{14} \mathrm{O}$ & $\begin{array}{l}\text { 2,4,5-Trimethyl- } \\
\text { benzenemethanol }\end{array}$ & 0.3 \\
\hline 8. & 1733 & 1733 & $\begin{array}{l}137(99.9), 180(78.3) \\
\text { 162(51.3), 124(50.2), } \\
91(49.1), 147(40.3) \\
\text { 119(34.5), 103(21.4), } \\
131(20.6), 77(20.1)\end{array}$ & $\mathrm{C}_{10} \mathrm{H}_{12} \mathrm{O}_{3}$ & $\begin{array}{l}\text { (E)-Coniferyl } \\
\text { alcohol }\end{array}$ & 2.8 \\
\hline 9. & 2111 & - & $\begin{array}{l}\text { 71(99.9), 82(72.8), } \\
95(71.5), 81(66.6), \\
\text { 123(58.7), 69(54.2), } \\
68(52.3), 57(51.2), \\
83(46.4), 55(43.2)\end{array}$ & - & Phytole ester & 0.4 \\
\hline 10. & 2399 & $2398^{*}$ & $\begin{array}{l}\text { 129(99.9), 112(42.0), } \\
\text { 147(30.7), 57(27.8), } \\
\text { 71(22.7), 70(21.6), } \\
\text { 111(20.2), 113(19.6), } \\
55(17.2), 101(10.6)\end{array}$ & $\mathrm{C}_{22} \mathrm{H}_{42} \mathrm{O}_{4}$ & $\begin{array}{l}\text { Bis(2-ethylhexyl) } \\
\text { adipate }\end{array}$ & 0.3 \\
\hline 11. & 2472 & - & $\begin{array}{l}55(99.9), 129(76.5), \\
69(73.7), 83(64.3), \\
81(53.2), 97(51.7), \\
98(49.1), 67(46.6), \\
95(42.7), 57(42.1)\end{array}$ & - & $\begin{array}{l}\text { Unidentified } \\
\text { compound }\end{array}$ & 0.7 \\
\hline & & & & & Total identified & 93.2 \\
\hline
\end{tabular}
column, LI - Adams' retention indices [13] and * - retention indices from NIST Chemistry WebBook [14].

In the studied alkaloid extract eleven components were identified, which make up $93.2 \%$ of the sample. The major components were lactone $y$-crotonolactone 
(78.6\%), followed by 3-methyl-2-butenal (8.6\%), and (E)-coniferyl alcohol $(2.8 \%)$. Other components were represented by less than $1 \%$. By comparing the obtained results with the published data on the alkaloid extract of $H$. telephium [6], there are differences in the qualitative and quantitative composition of the extracts.

The principal compound in each is lactone, but it originates from different acids: $y$-crotonolactone in the studied sample, and dehydromevalonic lactone (5.99\%) in $H$. telephium sample. With regard to alkaloid compounds, only nicotine $(0.4 \%)$ was identified in the studied AE-HS sample, while Gerelt-Od et al. (2015) identified 6 alkaloids ( 7\%): 3-methyl-2-carbethoxyindole (4.7\%), 2-(2-hydroxyphenyl)benzothiazole $\quad(1.6 \%), \quad \mathrm{N}, 4,5$-trimethylphenyl-1,2-diamine (1.2\%), 2-pyrrolidinecarboxy acid-5-oxo-, ethyl ester (0.9\%), 4-methyl-3,6-diisopropyl-2,5-diketo-morpholine (1.6\%) and 4-amino-3,5-diethylpyridine $(1.1 \%)$, but not nicotine [6]. Regardless of the origin of the studied hybrid (one of the parent species is $H$. telephium), it is obvious that the chemical composition of these two alkaloid extracts is quite different, both qualitatively and quantitatively. The members of the genus Hylotelephium have not been sufficiently investigated regarding alkaloids. The distribution on piperidine and pyrrolidine alkaloids within Crassulaceae is limited to the Sedum acre-group $[4,15]$. Among many other alkaloids, nicotine has been identified in the well-known stonecrop species - Sedum acre $[16,17]$. Certainly, it is necessary to do a more extensive analysis with numerous samples to determine a certain pattern of distribution of alkaloids within the genus Hylotelephium.

\section{Conclusion}

Data on the chemical composition of alkaloid extract of hybride $H$. spectabile $x$ telephium aerial parts were revealed for the first time. Also, the profiles of two alkaloid extracts were compared: the studied hybrid $H$. spectabile $\mathrm{x}$ telephium from the Republic of Serbia vs. the parent species $H$. telephium from Mongolia. The extract of $H$. spectabile $\mathrm{x}$ telephium, among many non-alkaloid compounds, contains $0.4 \%$ of nicotine (piperidine type alkaloids), while six alkaloids ( $7 \%$ ) were identified in parent species $H$. telephium from Mongolia [6]. Lastly, the alkaloid content in the studied sample is not significant and does not represent a confident scientific data by which we would claim that the representatives of this genus contain alkaloids. Further analysis alkaloid extracts of Hylotelephium taxa would shed light on the alkaloid profile and distribution.

\section{Acknowledgements}

Financial support of the Ministry of Education, Science and Technological Development of Serbia (Project No. 451-03-9/2021-14/200124) is gratefully acknowledge.

\section{References}

[1] M. H. A. Hassan, A. Elwekeel, A. Moawad, N. Afifi, A. Amin, D. E. Amir, Phytochemical constituents and biological activity of selected genera of family Crassulaceae: A review, South African Journal of Botany, 141 (2021) 383 $-404$.

[2] S. Č. Jovanović, O. P. Jovanović, Z. S. Mitić, T .D. Golubović, B. K. Zlatković, G. S. Stojanović, Volatile profiles of the orpines roots: Hylotelephium telephium (L.) H. Ohba, H. maximum (L.) Holub and H. spectabile (Boreau) H. Ohba x telephium (L.) H. Ohba, Flavour and Fragrance Journal, 32(6) (2017) 446 - 450.

[3] S. Mayuzumi, H. Ohba, The phylogenetic position of eastern Asian Sedoideae (Crassulaceae) inferred from chloroplast and nuclear DNA sequences, Systematic Botany, 29(3) (2004) 587 - 598.

[4] J. F. Stevens, H. 't Hart, H. Hendriks, T. M. Malingré, Alkaloids of the Sedum acre-group (Crassulaceae), Plant Systematics and Evolution, 185(3) (1993) 207 - 217.

[5] J. F. Stevens, H. 't Hart, R. C. H. J. Van Ham, E.T. Elema, M. M. V. X. Van Den Ent, M. Wildeboer, J. H. Zwaving, Distribution of Alkaloids and Tannins in the Crassulaceae, Biochemical Systematics and Ecology, 23(2) (1995) 157 $-165$.

[6] Ya. Gerelt-Od, A. Solongo, S. Javzan, S. Philipov, D. Selenge, Alkaloids from Sedum telephium L. Mongolian Journal of Chemistry, 42(16) (2015) $44-47$.

[7] R. Y. Cavero, S. Akerreta, M. I. Calvo, Medicinal plants used for dermatological affections in Navarra and their pharmacological validation, Journal of Ethnopharmacology, 149(2) (2013) $533-542$.

[8] M. Marković, V. Stankov-Jovanović, M. Smiljić, Medicinal flora of the Vidlič Mountain in Serbia, The University Thought-Publication in Natural Sciences 9(1) (2019) 17 26.

[9] G. Stojanović, S. Jovanović, B. Zlatković, A. Đorđević, G. Petrović, O. Jovanović, V. Stankov-Jovanović, Hylotelephium spectabile (Boreau) H. Ohba x Telephium (L.) H. Ohba leaf and flower extracts: composition, antioxidant and antibacterial activity, Records of Natural Products, 8(3) (2014) $272-276$.

[10] J. Wang, J. Wang, K. Liu, X. Xiao, W. Gong, Y. Lu, M. Liu, D. Xu, An efficient plant regeneration system with in vitro flavonoid accumulation for Hylotelephium tatarinowii (Maxim.) H. Ohba, In Vitro Cellular \& Developmental Biology - Plant, 46(5) 445 - 450.

[11] S. Y. Fung, J. Schripsema, R. Verpoorte, $\alpha, \beta$-unsaturatedY-lactones from Sedum telephium roots, Phytochemitry 29(2) (1990) $517-519$.

[12] D. W. Kim, K. H. Son, H. W. Chang, K. Bae, S. S. Kang, H. P. Kim, Anti-inflammatory activity of Sedum kamtshaticum, Journal of Ethnopharmacology 90(2-3) (2004) 409 - 414.

[13] R. P. Adams, Identification of Essential Oil Components by Gas Chromatography/Mass Spectroscopy, Allured Pub Corp; 4th edition, 2007, pp. 67, 187, 367, 666.

[14] NIST Chemistry WebBook, https://webbook.nist.gov/ chemistry/

[15] J. F. Stevens, H. 't Hart, H. Hendriks, T. M. Malingré, Alkaloids of some European and macaronesian sedoideae and sempervivoideae (Crassulaceae), Phytochemistry, 31(11) (1992) 3917 - 3924.

[16] L. P. S. Francis, G. W. Francis, Sedum alkaloids, Planta Medica, 32(07) (1977) 268 - 274. 
[17] S. Bieganowska, A. Waksmundzki, Alkaloids of the herb Sedum acre L. Part I, Chromatographic analysis, 9(5) (1976) $215-218$.

Izvod

\section{HEMIJSKI SASTAV ALKALOIDNOG EKSTRAKTA IZOLOVANOG IZ NADZEMNOG DELA BILJKE HYLOTELEPHIUM SPECTABILE (BOREAU) H. OHBA X TELEPHIUM (L.) H. OHBA}

Miloš G. Đukić, Jelena M. Jovanović, Gordana S. Stojanović, Snežana Č. Jovanović

(ORIGINALNI NAUČNI RAD) UDK 582.711.16:547.94

DOI 10.5937/savteh2102005D

Departmant za Hemiju, Prirodno matematički fakultet, Univerzitet u Nišu, Niš, Srbija

Postoji mnogo motiva za proučavanje alkaloida unutar porodice Crassulaceae, poput hemotaksonomskog razmatranja distribucije alkaloida i procene njihovog biološkog potencijala. Podaci o alkaloidima Sedum telephium (sin. H. telephium) pobuduili su interesovanje za dalja istraživanja alkaloida u okviru roda Hylotelephium $\mathrm{H}$. Ohba. Cilj ove studije bio je ispitati druge biljne izvore alkaloida iz istog roda i okarakterisati hemijski sastav alkaloidnog ekstrakta. Alkaloidini ekstrakt (AE-HS) izolovan je iz svežih nadzemnih delova kultivisanog hibrida $H$. spectabile x telephium. Hemijski sastav AE-HS određen je metodom GC-MS (gasna hromatografija-masena spektrometrija). Identifikovano je osam komponenti $(91,8 \%)$. Najzastupljenija komponenta AE-HS je y -krotonlakton (78,6\%), zatim 3-metil-2-butenal $(8,6 \%)$ i $(E)$ - koniferil alkalohol (2,8\%). Nikotin je identifikovan kao jedini alkaloid AE-HS $(0,4 \%)$. Pored mnogih nealkaloidinih jedinjenja, prethodna studija otkrila je šest alkaloida u AE $S$. telephium $(\sim 7 \%)$, što nagoveštava razlike u odnosu na naše rezultate. Pripadnost istom rodu ne znači ujednačen kvalitativni sastav. Svakako dalje analize AE taksona Hylotelephium rasvetlile bi obrazac distribucije alkaloida.
Ključne reči: Hylotelephium spectabile $\mathrm{x}$ telephium, alkaloidi, GC-MS analiza 